InVisible Culture • Issue 31: Black Studies Now and the CounterCurrents of Hazel Carby

\title{
Susceptible Archives
}

\section{Anne Anlin Cheng 1}

${ }^{1}$ Princeton University

Published on: Nov 15, 2020

DOI: $10.47761 / 494 a 02 f 6 . d c 2523 c 2$

License: Creative Commons Attribution 4.0 International License (CC-BY 4.0). 
In Thinking Orientals: Migration, Contact and Exoticism in Modern America, a study of early Asian American sociologists who contributed to the birth of the famous Chicago School of Sociology, Henry Yu addresses the paradoxes of and for racialized intellectuals engaged in the construction of counter-narratives (that are sometimes narratives of self-identification) in the service of the production of academic knowledge. He reminds us that the racialized scholar is not free from "the ethnographic imagination," defined as the task of "making a place seem strange and then gradually replacing the confusion with knowledge that make the place and the people seem familiar enough to be understandable and perhaps even admirable. $\underline{1}$ What Hazel Carby has done in her new book, Imperial Intimacies, is to turn this insight inside out, making us see that it is not the packageable and digestible narratives of selfidentification that may be risky but rather it is the impossibilities and the fractures of a narrative of self-identification that can contest history. It is the profound selfestrangement within Carby's project-a schism tentatively bridged but never fully replaced by the imagination-that reveals the imbrications and gaps between "selfknowledge" and "academic knowledge." In the relation between these two, Imperial Intimacies returned me to the politics and ethics of being and becoming a racialized intellectual at present, and to the hermeneutics of susceptibility I have advocated elsewhere. $\underline{2}$

As Carby writes in her preface, "[This] is the story of the everyday ties, relations and intricate interdependencies of empire and colonialism." $\underline{3}$ To tell this story, Carby draws from what is there and what is not there in the National Archives of Jamaica and the UK, just as she both turns to and puts aside private memories, a source that carries its own riches and absences. Like other scholars today who are bringing attention to the challenges of missing archives, Carby is searching for a new form of critical expression, one that can accommodate that which remains hidden, disguised, denied, or refuses to be passed on. Here she has constructed her version of what Allan Sekula calls a "shadow archive": the invention of an inclusive social context which supplements and haunts disparate, traditional archives. $\underline{4}$ In this light, the most difficult challenge facing the racialized intellectual doing race work, Carby shows, is not one of representation, as is often posed, but a deeper and more fraught epistemological negotiation among memories public and private, the fraught demands of desire, the pulls of affective allegiances and political commitments-all of which can be layered, contradictory, and mediated. 
While much recent work on the archive underscore what is missing from public record, what Carby unfolds is a dilemma of discovery: a moment of finding that is also an unfinding. In the archive, Carby was able to locate her name, its British origins, its glaring entanglement with slavery, and what it means to bear a surname that both marks and refuses you. She finds herself on both sides of the ledger, so to speak. The fact that slave owners give their surnames (and often even the first names of their sons and daughters) to their slaves signals both an act of disturbing familiarity and ruthlessly casual ownership. What Carby offers is not a narrative of self-identification but a drama of the epistemological crisis engendered by a name. What's in a name? A genealogy of contradictions, of violence, and a record of familial care tenuously carved out within the shadow of that violence.

It is therefore not a coincidence that this book is preoccupied with names and naming: as inscriptive and conscriptive categories, as causal lines on a slave ledger, as gambits for respectability in church records, as sites of recovery and symbols of erasure, as a raw reminder of a history of human ownership and the perversely familial relations of colonial oppression-in short, imperial intimacies. So much has been written about the British Empire, and yet shockingly little has been done to explore with this kind of scope and detail, with this level of honesty and compassion, its particular and peculiar production of race and mixed-racedness, itself also a notably under-theorized concept. Imperial Intimacies meditates on "mixed-racedness" on multiple levels: as splinters in a family tree; as affective contradictions and allegiances; as psychical ruptures; as an intellectual commitment against Manichean differences, especially when it comes to the processes and consequences of racialization; and, finally, as the animating inspiration for this book's textual strategy, drawing from and creating a confrontation among legal documents, historical records, personal letters, maps, and photographs. This book reads like a multi-media narrative but is deeply rooted in the archives; it offers a central narrating voice but one that is fractured, not only scholar and/but-also woman, not only daughter and/but-also researcher, not only adult and/but-also child. Carby chooses, for instance, to refer to her child self in the third person because it is clear that that child experienced a depth of painful, often ineffable, experiences that the adult can barely assimilate. There is no simple "I" here, which is the point.

Given Carby's complex understanding of what it means to be a child of empire who is now a distinguished scholar of race, and the abiding movement between selfknowledge and academic knowledge this double consciousness brings with it, the usual debate around identity politics seems woefully emaciated, leading to a series of unproductive and irresolvable paradoxes. In spite of our cultivated impatience with 
identity politics and attending notions of essentialism, those of us working in a field or fields organized under so-called identificatory rubrics continue to engage with identity politics and its contradictions: the fact that it offers a vital means of individual and communal affirmation as well as represents a persistent mode of limitation and reinscription. The double-edge of recognition (identity being the same ground on which both affirmation and objectification are made) is also the reason why identitydriven fields of inquiry in the academy have both acquired institutional recognition in the last fifty years as well as continued to suffer from what Carby has long ago called "cultural apartheid." $\underline{5}$ Even as fields such as race and ethnic studies seem to be gaining institutional grounds, they often remain segregated from the traditional and unquestionably legitimized disciplines, such as English, History, or Sociology. Although "diversity" is an idea touted by almost all universities today, what the term means remains narrow and often unassimilated into "core curriculum." We see it in the academy's continual struggle over the meaning and practice of Affirmative Action. We see it in how curriculums are organized. How many of us have sat through departmental discussions about how "core courses" must take precedence over the "nice" but finally secondary or tertiary demands of African American studies or Asian American studies? Recently, in a debate about a proposal to make "Diversity and Difference" a university-wide requirement in undergraduate education, I heard a political scientist, whose training would seem to disallow the following claim, oppose the proposal by pointing out that "scholarship should not be political." For some, there is no relation between self-knowledge and academic knowledge.

This willful insistence on scholarship's supposed "objectivity" not only elides how power has historically structured knowledge but also jeopardizes the professional status of the racialized intellectuals in the academy. In that discussion about university diversity requirements, the scholars of color in the room were all effectively silenced, for their support can only be taken as self-interests. Similarly, as Carby pointed out decades ago, scholars of color in the American university system are valued in some ways and often made highly visible, yet their number remains, to this day, significantly low. Indeed, much of what Carby wrote in the early 1990s on the so-called "multicultural wars" remains troublingly on point: that the woman of color is always asked to represent (to operate under what Claudia Tate called the "protocols of race"); $\underline{6}$ that she is always reproduced as Other by both distractors and rescuers alike; that popular appetite for black cultural production often substitutes for social and political engagement; that the war over "multicultural curriculum" in the 80s and 90s (whether 
the attention to multiculturalism is intellectually sound or merely politically driven) is really a war over the profound and stubborn tension between scholarship and politics. $\underline{7}$

This struggle between scholarship and politics goes right to the heart of current debates about what we do as readers and interpreters of texts. Here I am thinking about the ongoing anxiety about the so-called "hermeneutics of suspicion" so often attached to the critique of power. In recent years, the critique of power, which tends to rely heavily on a hermeneutics of suspicion and what is called "symptomatic reading," has come under attack for reproducing entrenched ideologies of its own. In his essay “Why Has Critique Run Out of Steam?” Bruno Latour tells us that a hermeneutics of nothing but suspicion has led us to the death of "the critical spirit." $\underline{8}$ He contends that, in the eagerness to expose hidden ideological contents, contemporary criticism has replaced iconoclasm with more iconoclasm, reconstituting the critic as the source of epistemological mastery who, in his words, "ceaselessly transform the whole rest of the world into naïve believers ...fetishists...[and] hapless victims of domination." $\underline{9}$ Meantime, on the other side of the fetishistic projections, critics are eager to locate notions of individual agency or authenticity claims as redemptive antidotes. In other words, we keep circling within the moebius band of identity-demands.

When it comes to the future of race studies, however, I am less concerned that reading for symptoms might produce, as Latour is, "illusions of prejudice" where there are none. There remains plenty of prejudices to be found. But I do take to heart his insight that all this reading-for-what-is-underneath has produced a stable object/subject (reader/text) dyad that is not only illusory but has also blinded us to what the complicity of those terms might teach us. Can we imagine, in the future of humanist critical practices, a hermeneutics beyond suspicion? How do we acknowledge the susceptibility endemic to being a child of empire, of colonialism, and, today, of neoliberalism?미 I am much more interested in understanding subjects and objects in structures of power as both wayward and vulnerable, which is why the figure of the scholar/woman/child in the archives in Imperial Intimacies is so compelling. She shows us that what is urgently at stake in confronting the legacies of power is less a question of identity than a question of identification: how we must attend to the unruly processes that make identity (the fiction of the "I") possible in the first place, but that also constantly threaten the integrity of that illusion. $\underline{11}$

Carby has always been clear-eyed about the limits of "difference" as an institutional corrective. In her influential essay "The Multicultural Wars," she asked pointedly: 
“[D]ifferent from and for whom?”1ㅡ There are so many double binds haunting the institutionalization of "race" and "ethnicity" and the scholars who work within the institutions. Imperial Intimacies exposes not only the simplicity but also the falseness underlying both the fetishization of difference and the distinction between race studies and the rest of the humanities. It reminds us that "English" and "Englishness" are also identity fields, organized around an imagined, integral identity that is in fact composed of multiple, suppressed identities. English studies, from the days of Anglo-Saxon struggles through the making of the British Empire and its aftermath in modernity, Carby insists, is race studies. The making of the British subject (in myriad shades of white, brown, and black) emerges out of encounters with otherness and is fortified through deliberate memory and forgetting. For Carby, her extraordinary account of her heritage is not singular, but very British: "Links to colonial exploitation and oppression, to Atlantic slavery and imperial wars, are not the exception, they are our quotidian past." 13 This "tale of two islands" is another strand in what Lisa Lowe would call the intimacy of continents. $\frac{14}{}$

Carby draws vast (imperial and personal) lines and connections between England, Wales, and Jamaica. She teaches us that violence happens on many scales and that those violences are interconnected and diachronic. What happened between England and its colonies in the nineteenth century is directly linked to what happened to a brown child growing up in the suburbs of England in the 1950s. The global and the domestic, the social and the familial-these are all interpenetrating sites. History is not large impersonal forces but the closely layered and intimately frayed interactions of individuals, however invisible they are to this history. And if the self is usually thought to promise knowledge of who I am, then Carby's work breaks down the fictions and frictions of that promise in the shadow of empire and power.

The problem with power has never been only that it oppresses a whole and complete person but that it compromises the very conceptualization of personhood and subjecthood in the first place. This is true of the poor, lowly-born white man who comes to dominate other human beings in the tropical colonies and who named his enslaved properties after his family members back in England (as Carby's ancestor did). It is true of the young Welsh woman who crossed the room to dance with a young Jamaican man and then crossed an even bigger line to marry him, only to never fully accept their differences (as Carby's mother did). It is true of the Kingston-born man who served proudly in the Royal Air Force and hung on to his Britishness even when England was trying to deny him his citizenship (as Carby's father did). And it is most 
certainly true of the mixed-raced young woman who has to find her way through the multiple and fractured selves within the composed scholar.

I had asked whether we can imagine a hermeneutics, not of suspicion, but of susceptibility. It seems to me Carby offers us one such model by radically undermining the divisions between public and private, scholar and woman, as well as a host of binary terms that dog discussions of racial encounters. The problem with binary thinking is that it can never exceed its own terms. Take for example the moral certitude that drives corrective readings of phenomena such as Primitivism and Orientalism, the two most extensive and enduring racial discourses of Euro-American cultures. Appropriation and commodification remain our most cherished weapons of critique against the ills of racist consumption. But appropriation/projection as the sole mode of understanding the relationship between the West and its racial other has produced its own limitations. Are "fetish" or "fact" really the only two options for the racialized subject?

The artists and scholars whose works to which I return again and again are those who refrain from easy moral certitude, who are willing to confront the extreme and quotidian manifestations of human horror without the full reassurances of redemption or recovery. For me, this reticence registers an ethical decision: a decision to remain in the gift of discomfort and dislocation. Robert Frost once wrote, "Grievances are a form of impatience. Griefs are a form of patience."토 I took that as an epitaph for my first book as a reminder to myself: to be patient, to have the courage to not hurry past grief to get to grievance because the latter is less hurtful and gives the illusion of agency. We do not need to read Hazel Carby to confirm for us the "fact" of racism or the "fetish" of race. We have the news for that. We read Carby to understand the radiating afterlife of discrimination, its unruly etiology, and the education of desire that it has instilled in both the dominant and minority subject. The ethical relation that we must imagine is one that accounts for, rather than negates, these paradoxes.

There's a line from the poet Sally Wen Mao that keeps popping into my head: "The story of our lives do not have faces."16 I think of Imperial Intimacies as doing similar work: tracing, without congealing, the phantasmal relics of our complicated social and psychical histories, especially as subjects of color. It should not surprise us that this haunting book can also be read as a long epistolary communication, addressed to those who may not be there to receive it: written to a profession that has both touted and sidelined an entire field of inquiry; to a child-self who is gone but still asking to be accounted for; to a mother who struggles against the consequences of her own 
courage; and, perhaps most poignantly, to a now fading father who spent his life exercising his gentlemanliness and Britishness as defense against a brutalizing world. In the end, is it any wonder that the daughter and granddaughter of two accomplished seamstresses should now undertake a project that weaves together so seamlessly and so traumatically the palimpsest of history, life, politics, and memory?

\section{Footnotes}

1. Henry Yu, Thinking Orientals: Migration, Contact, and Exoticism in Modern America (New York: Oxford University Press, 2002), 35. $\subseteq$

2. Anne Anlin Cheng, "Psychoanalysis Without Symptoms," differences 20, no. 1 (Spring 2009): 87-101.

3. Hazel V. Carby, Imperial Intimacies: A Tale of Two Islands (London: Verso, 2019), 1. $\doteq$

4. Allan Sekula, "The Body and the Archive," October 39 (Winter 1986): 3-64.

5. Hazel V. Carby, "Can the Tactics of Cultural Integration Counter the Persistence of Political Apartheid? Or, The Multicultural Wars, Part Two," in Race, Law and Culture: Reflections on Brown v. Board of Education, ed. Austin Sarat (New York: Oxford University Press, 1997), 221-8.

6. Claudia Tate, Psychoanalysis and Black Novels: Desire and the Protocols of Race (New York: Oxford University Press, 1998). $\_$

7. The tension between scholarship and politics can be found even among the ranks of race scholars. Consider the famous debate in 1987 between Barbara Christian and Henry Louis Gates in Critical Inquiry over the ability versus inability of "high theory" to address racialized subjects and their products, or the debate more than a decade later between Henry Louis Gates and Manning Marable. See Henry Louis Gates, "Authority, (White) Power and the (Black) Critic: It's All Greek to Me" and Barbara Christian, "The Race for Theory," Critical Inquiry 7 (Autumn, 1987): 19-46, 51-63; Henry Louis Gates, "A Debate on Activism in Black Studies: A Plea That Scholars Act Upon, Not Just Interpret, Events," and Manning Marable, "A Call to Protect Academic Integrity from Politics," New York Times, April 4, 1998, A13, A15. 8. Bruno Latour, "Why Has Critique Run out of Steam? From Matters of Fact to Matters of Concern," Critical Inquiry 30 (Winter 2004): 225. 
9. Latour, "Why Has Critique Run out of Steam?" 225. $\subseteq$

10. For thinking about what it means to be a child of neoliberalism, I highly recommend the recent film Parasite (2020). See Anne Anlin Cheng, "The Shell Game: From Get Out to Parasite," Los Angeles Review of Books, February 21, 2020, https://www.lareviewofbooks.org/article/shell-game-get-parasite/..

11. As Diana Fuss eloquently puts it, "Identification is a process that keeps identity at a distance, that prevents identity from ever approximating the status of an ontological given, even as it makes possible the formation of an illusion of identity as immediate, secure, totalizable." Diana Fuss, Identification Papers (New York: Routledge, 1995), 2.

12. Hazel V. Carby, “The Multicultural Wars,” Radical History Review 54 (1992): 12.

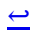

13. Carby, Imperial Intimacies, 334.

14. Lisa Lowe, The Intimacies of Four Continents (Durham: Duke University Press, 2015).

15. Robert Frost, The Robert Frost Reader: Poetry and Prose (New York: Holt Paperbacks, 2002), 391; quoted in Anne Anlin Cheng, The Melancholy of Race: Psychoanalysis, Assimilation, and Hidden Grief (New York: Oxford University Press, 2001), vii. $\subseteq$

16. Sally Wen Mao, "No Resolution," in Oculus (New York: Greywolf Press, 2019), 1718. $ヒ$ 